\title{
A VARIAÇÃO “TU" E "VOCÊ" NO PORTUGUÊS BRASILEIRO OITOCENTISTA E NOVECENTISTA: REFLEXÕES SOBRE A CATEGORIA SOCIAL GÊNERO. ${ }^{1}$
}

\author{
Márcia Cristina de Brito RUMEU*
}

- RESUMO: Neste texto, discute-se a relevância da categoria social gênero para a interpretação do processo de inserção do Você no Português Brasileiro. Com base na análise de missivas pessoais oitocentistas e novecentistas redigidas por brasileiros cultos e integrantes de uma mesma família brasileira (a família Pedreira Ferraz-Magalhães), cujos perfis sociolinguísticos foram identificados (LOBO, 2001), discutem-se os resultados de um estudo de painel (LABOV, 1994), voltado para sincronias passadas do PB, em relação às formas Tu e Você como sujeitos pronominais. Evidencia-se que o Você, empregado informalmente em cartas brasileiras entre os anos 20 e 30 do século XX, está em avançado estágio de mudança linguística, sendo tal processo conduzido pelas mulheres. À discussão, acrescentam-se os resultados do estudo da variação Tu/Você, feito por Pereira (2012) com base em cartas redigidas por brasileiros da ilustre família Penna, em fins do século XIX e na primeira metade do século XX, expondo o gênero como uma categoria social propulsora da inserção do Você no sistema pronominal do Português Brasileiro oitocentista e novecentista.

- PALAVRAS-CHAVE:Variação tu/você. Mudança linguística. Gênero. Pronomes de tratamento. Sistema pronominal.

\section{Considerações iniciais}

A reflexão sobre a função do gênero como uma categoria frequentemente selecionada em análises sociolinguísticas que envolvem a flutuação entre as formas Tu e Você (LOPES; MACHADO, 2005; RUMEU, 2008; PEREIRA, 2012) se insere numa discussão maior acerca da norma escrita culta do português brasileiro (doravante PB). Nesse sentido, a ponderação proposta neste artigo acerca da representatividade da categoria social gênero está fundamentada na produção escrita de brasileiros cultos, unidos por laços familiares no decorrer de suas vidas, em fins do século XIX e na primeira metade do século XX. Com base nessas amostras oitocentistas e novecentistas de missivas familiares, produz-se

* UFMG - Universidade Federal de Minas Gerais. Faculdade de Letras. Belo Horizonte - MG - Brasil. 31.270-901 -marciarumeu@uol.com.br

1 Apoio: Programa de Auxílio à Pesquisa de Doutores Recém-Contratados, financiado pela Pró-Reitoria de Pesquisa da Universidade Federal de Minas Gerais (PRPq-UFMG). 
um estudo de painel, nos moldes Labovianos (panel study, cf. LABOV, 1994), sobre a variação entre as formas Tu e Você e a inserção do Você no sistema pronominal do PB. As cento e setenta cartas produzidas por integrantes da família Pedreira Ferraz-Magalhães que embasam este estudo de painel constituem parte da produção escrita culta de brasileiros cujos perfis sociolinguísticos foram criteriosamente controlados, à luz de Lobo (2001). A apreciação da categoria social gênero é incrementada com a discussão de alguns dos resultados da análise variacionista das formas relacionadas a P2 (Tu) e a P3 (Você), proposta por Pereira (2012), com base em cartas familiares e amorosas, produzidas pelos brasileiros da família Penna, em fins do século XIX e na primeira metade do século XX.

Assumindo um comportamento diverso do caminho seguido pelo Você, a partir do século XIX, em Portugal, a aristocracia brasileira emprega tal forma inovadora nos Oitocentos, como evidencia Soto (2001), com base na análise de missivas brasileiras oitocentistas e novecentistas. $\mathrm{O}$ fato de Você ainda resguardar o prestígio da Forma Nominal de Tratamento para a realeza que a originou (Vossa Mercê) demonstra o conservadorismo do PB. Por outro lado, o emprego de Você (SOTO, 2001), em cartas-diário, pela Condessa de Barral, ao se referir ao imperador D. Pedro II - como se observa em (01) -, e entre os amigos baianos Rui Barbosa e José Marcelino (senador e governador da Bahia), em cartas pessoais trocadas em 1904 e $1906^{2}$ - respectivamente, em (02) e (03) (MENON, 2006) - já não seriam indícios do acelerado processo de dessemantização sofrido pelo Você a assumir, no Brasil, o inovador domínio da solidariedade? Como depreender o uso linguístico mais informal dessa elite letrada brasileira em sincronias passadas do PB a partir da produção escrita de uma pequena parte da população brasileira socialmente privilegiada que não teve uma produção escrita regular? O que teria motivado o Imperador D. Pedro II a tratar a amiga Condessa de Barral, mulher da elite brasileira, com o inovador Você? E o que teria movido a Condessa de Barral a retribuir tal tratamento íntimo ao Imperador do Brasil D. Pedro II, conforme averiguado por Soto $(2001,2007)$ ? O que teria levado a missivista mineira Maria Guilhermina Penna, casada com o ex-presidente da República Affonso Pena, a optar por tratar o filho Affonso Penna Júnior, como se observa em (04), por Você, sobretudo, ao atingir a velhice (PEREIRA, 2012)? O que teria impulsionado a Vovó Bárbara Ottoni - redatora mediana nos termos de Barbosa (2005) - a também preferir, no Brasil de fins do século XIX, o Você para fazer referência aos seus netos, como se verifica em (05)?

Segundo Menon (2006), a carta de José Marcelino para Rui Barbosa é de 27.06.1904 e a carta de Rui Barbosa retribuída a José Marcelino é de 12.10.1906. 
(1) Excertos de Cartas da Condessa de Barral e do Imperador D. Pedro II, em 1869:

"Condessa de Barral: Eu fiquei tão contente que nem sei como pude descer a escada do colégio. Meu pensamento foi de Montmartre ao Brasil e $\underline{\mathbf{V}}$. havia de sentir o fluido pelo seu coração."

Imperador D. Pedro II: "Ah! se senti! Você sabe que bem lhe quero!" Condessa de Barral: "Ah! Se sei!" (SOTO, 2007, p.159).

(2) Carta de José Marcelino, em 27 de junho de 1904:

"José Marcelino a Rui Barbosa: Caro colega e amigo Rui Barbosa. [...] Conhece

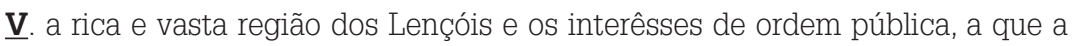
administração tem de atender, ali, onde são frequentes as perturbações. [...] Conhece $\underline{\mathbf{V}}$. melhor que eu a questão da propriedade dos terrenos de marinha e das minas [...] e perante o Congresso e o Govêrno Federal a Bahia entrega-se a $\underline{\mathbf{V}}$. e a todos os seus representantes, dos quais deve $\underline{\mathbf{V}}$. ser o centro de ação por todos os titulos." (MENON, 2006, p.153).

(3) Carta de Rui Barbosa, em 12 de outubro de 1906:

"Rui Barbosa a José Marcelino: Felizmente recebi do Severino, ontem, um telegrama, onde me diz: 'Louvo-me no seu pensar e sentir; sou solidário seu modo de agir'; e $\underline{\mathbf{V}}$. mesmo termina o seu com estas palavras: 'Resolva o que seu espírito esclarecido, criterioso e experimentado the ditar [...]" (MENON, 2006, p.153).

(4) Carta de Maria Guilhermina Penna a Affonso Penna Júnior, em 01 de março de 1909: "Vocé tem recebido 20 volumes que o Mordomo mandou? Escrevi uma carta de 4 paginas e vocé diz que não recebeu, não gostei nada d'isso. [...] Pela semana Santa vocé poderia vir nos visitar; e trazer ao menos o Helvecio Sim? Tenho muitas saudades delle e da Eunice. Faço ideia como estarão engraçadinhos." (PEREIRA, 2012, p.108).

(5) Carta 41 da avó Barbara Ottoni ao neto Mizael, em fins do século XIX:

"A 12 escrevi a Christiano e hoje a voce. Estimei muito as boas noticias que tive que voce está muito estudiozo e que está muito adiantado. Continue para nos dar muito gosto e a sua Mae aquem abraçarás por mim. Aqui é uma monotonia, que so seouve abulha do Rio, que fas um atordoamento, que é pior do que o silencio. Teabraça e a Christiano Sua Avo e Amiga. Barbara." (LOPES; MACHADO, 2005, p.53).

A complexidade dos usos tratamentais, como se sabe, não se limita ao valor semântico-social que uma determinada forma de tratamento carrega em si, mas aos valores que os falantes podem atribuir a elas, nas diferentes situações comunicativas que, por si sós, são também complexas. Ao mesmo tempo em que Você é utilizado pela elite, em cartas do então imperador D. Pedro II, aparece, no mesmo século, generalizado no uso doméstico nas cartas da vovó Bárbara 
Ottoni (LOPES; MACHADO, 2005). O que alguns trabalhos sobre o tema (LOPES; DUARTE, 2003; RUMEU, 2004; BARCIA, 2006; MACHADO, 2006; MARCOTULIO, 2008) têm mostrado é que, a partir do século XVIII, a forma vulgar Você torna-se produtiva nas relações assimétricas descendentes de superior para inferior, podendo até assumir, em algumas situações sócio-pragmáticas, "conteúdo negativo intrínseco ", em oposição à sua contraparte desenvolvida Vossa Mercê. Por outro lado, no Brasil do século XIX, a concorrência passa a ser maior entre Tu e Você em relações solidárias mais íntimas, não sendo tal estratégia negativamente marcada. Essa aparente contradição advém da própria origem e do processo de mudança ${ }^{3}$ de Vossa Mercê>Você, na medida em que passou a apresentar divergência gradativa do tratamento-fonte (Vossa Mercê) e passou a concorrer com o solidário Tu nos mesmos contextos funcionais. Do "tratamento nominal abstrato"4 (Vossa Mercê), nos termos de Koch (2008, p.59), herdou o caráter indireto, por isso seria menos invasivo, menos "ameaçante ao interlocutor" e, dessa forma, funcionou como a estratégia preferida pelas mulheres na sociedade brasileira do século XIX (LOPES; MACHADO, 2005; SOTO, 2001; RUMEU, 2008; PEREIRA, 2012).

Partindo-se do pressuposto de que o Você é uma forma que surgiu posteriormente a Tu e que com ele compete no PB como uma forma menos invasiva, propõem-se as seguintes questões: (1 $\left.1^{a}\right)$ a variável gênero (sexo) poderia representar um fator de progressão (avanço) ou de regressão (retrocesso) na direção da implementação de uma nova variante (Você) no sistema pronominal?; $\left(2^{\mathrm{a}}\right)$ a opção por Tu ou por Você estaria correlacionada com o papel social assumido por homens e mulheres na realidade sócio-histórica e linguística do PB oitocentista e novecentista?; ( $3^{a}$ ) as mulheres da família Pedreira Ferraz-Magalhães, ao preferirem o inovador Você, poderiam ser consideradas inovadoras, conforme previa Labov (1990)?

Considerando os resultados de outros estudos sobre o tema na tentativa de depreender como e quando o Você suplanta o Tu no PB, postula-se que, em fins do século XIX e no século XX, o Você ainda conserve uma relativa formalidade, mas se manifeste, por outro lado, em alternância com o $\mathbf{T u}$. Em outras palavras, entende-se que ainda que o Você viesse sendo empregado, desde o século XIX, como forma de tratamento da elite brasileira, representada pelo imperador Dr. Pedro II e pela condessa de Barral (SOTO, 2001, 2007), e pela esposa do Presidente da República Brasileira ${ }^{5}$, Maria Guilhermina Penna (PEREIRA, 2012), já se mostrava

Trata-se de um caso de gramaticalização já discutido em outros trabalhos tais como os de Lopes e Duarte (2003), Rumeu (2004), Barcia (2006) e Machado (2006).

4 "O tratamento abstrato se compõe de um adjetivo possessivo (que se refere ao interlocutor) e de um substantivo abstrato (que indica uma qualidade ou uma posição social atribuída ao interlocutor." (KOCH, 2008, p.59-60).

5 Affonso Penna foi Presidente da República Brasileira, aos 59 anos, no alvorecer do século XX, mais especificamente em 1906. 
generalizado no uso doméstico dos Ottoni (LOPES; MACHADO, 2005). Acrescentese o fato de ser a mulher da família Ottoni (Bárbara Ottoni) a responsável pelo emprego de tal inovação linguística na intimidade da relação entre avó-netos (crianças) e mãe-filha. Partindo dessas observações, busca-se, neste estudo, testar a hipótese Laboviana (LABOV, 1990) de que as mulheres tendem a alavancar os processos de mudança linguística, sendo assim consideradas inovadoras.

Acompanha-se a produção escrita da família Pedreira Ferraz-Magalhães basicamente em três gerações ${ }^{6}$. A primeira geração é a do Dr. Pedreira (patriarca da família), que escreve aos filhos e aos netos no contexto histórico-social da corte carioca em fins do século XIX. A segunda geração é a de Zélia (filha do Dr. Pedreira e matriarca da família) que escreve aos seus filhos em inícios do século XX. A terceira geração é a dos filhos de Zélia (netos do Dr. Pedreira), que trocaram correspondências entre si, no interior dos conventos do Brasil e do exterior, no decorrer da primeira metade do século XX. Destaque-se que, com base na produção escrita desses informantes cujos perfis sociais - origem (nacionalidade e naturalidade), filiação, idade, gênero (sexo), nível de escolaridade, representação social - foram identificados, seja possível entrever as redes de relações sociais tecidas entre brasileiros que nasceram e viveram no Brasil imperial e republicano. Assumindo o objetivo de vislumbrar a expressão da escrita informal de fato praticada por escreventes letrados, pertencentes a uma abastada e conservadora família rigidamente vinculada aos valores do catolicismo cristão, pretende-se, através da proposta de confecção de um estudo de painel (panel study), pensado por Labov (1994), depreender especificamente o comportamento linguístico dos membros da família Pedreira Ferraz-Magalhães em relação as suas escolhas tratamentais, em fins do século XIX, assim como na primeira metade do século XX.

Este texto está assim estruturado: nas considerações iniciais, apresentam-se as diretrizes e questões norteadoras da investigação e a hipótese que a conduz. Em seguida, caracterizam-se os corpora diacrônicos (cartas familiares dos Pedreira Ferraz-Magalhães) que subsidiam o estudo de painel voltado para a diacronia do PB. Na próxima seção, esclarecem-se os pressupostos teórico-metodológicos que fundamentam esta análise linguística à luz da Teoria da Variação de orientação laboviana, assim como se comentam alguns resultados de trabalhos de base sociolinguística nos quais o gênero se mostrou uma categoria social importante para a compreensão da natureza de fenômenos variáveis nas línguas humanas. Na sequência, passa-se não só à apresentação dos resultados do estudo de painel dos missivistas (panel study) (LABOV, 1994), desenvolvendo a discussão sobre a função da categoria social gênero, mas também à discussão dos resultados

Rumeu (2008) dispôs, à comunidade acadêmica, a edição diplomático-interpretativa de cento e setenta cartas familiares produzidas por "mãos" legitimamente brasileiras, representadas pelos Pedreira Ferraz-Magalhães. 
da análise variacionista das formas Tu e Você, em cartas familiares e amorosas produzidas por brasileiros da família Penna, em fins do século XIX e na primeira metade do século XX, tecida por Pereira (2012). Por fim, chega-se às considerações finais acerca da relevância da categoria social gênero para a análise da variação Tu/Você nas realidades oitocentista e novecentista do PB.

\section{As cartas dos Pedreira Ferraz-Magalhães: uma família brasileira culta no alvorecer do século $\mathrm{XX}$}

A edição de corpora representativos da modalidade do português desenvolvida em terras d'aquém mar se justifica pelo objetivo/intuito de subsidiar análises linguísticas confiáveis em relação à realização objetiva da norma culta escrita do português do Brasil que, segundo Pagotto (1999), foi habilmente fixada "à imagem e semelhança" do português europeu (doravante PE) e amparada pela força do discurso científico, no Brasil do século XIX. Acredita-se que se esteja ampliando a perspectiva de análise adotada por Rumeu (2004), que editou, naquele momento, corpora representativos da escrita culta da língua portuguesa no Brasil (português no Brasil). Em tal edição de cartas da administração pública e privada, produzidas na realidade sócio-histórica do Brasil setecentista e oitocentista, não se dispunha de informações acerca da origem de todos os missivistas (brasileiros ou portugueses), por isso tais amostras de textos foram consideradas representativas do português no Brasil dos séculos XVIII e XIX e não, do português do Brasil. A base deste estudo está alicerçada em um maior grau de refinamento da amostra constituída pela edição diplomático-interpretativa, com fac-símile de cento e setenta missivas redigidas por informantes seguramente identificados em relação à sua origem brasileira e ao seu nível de escolaridade (culto).

O conceito de "culto" para o período precisa ser redefinido. Consideram-se como cultos não só os missivistas que estudaram, dedicaram-se à vida religiosa como padres e se tornaram bacharéis (João Pedreira do Couto Ferraz, Jerônimo de Castro Abreu Magalhães, Fernando Pedreira de Abreu Magalhães, Jerônimo Pedreira de Abreu Magalhães - Pe. Jerônimo), mas também as filhas do casal Zélia Pedreira de Abreu Magalhães e Jerônimo de Castro Abreu Magalhães, que só se dedicaram à vida religiosa no interior dos conventos (Maria Bárbara, Maria Elisa, Maria Joana, Maria Leonor e Maria Rosa). Apesar de não haver indícios de que essas mulheres religiosas tenham chegado a concluir um curso superior, é possível assumi-las como informantes cultas do PB devido à "bagagem intelectual" que adquiriram por terem nascido no seio de uma abastada família brasileira oitocentista. No aconchego do lar da família Pedreira Ferraz-Magalhães, valorizava-se o ensino de línguas (inglês), das ciências, da música, da literatura, 
conforme Castro (1960), difundindo-se, pois, a cultura num sentido mais amplo. Além disso, acrescente-se o fato de os nove filhos de Zélia (a matriarca da família Pedreira Ferraz-Magalhães), que seguiram a vida religiosa em distintos conventos do Brasil, além de outras atividades exercidas nas respectivas instituições a que pertenciam, terem se envolvido com o ensino dos jovens, segundo Castro (1960).

As missivas pessoais trocadas entre os membros da família Pedreira Ferraz-Magalhães expõem a intimidade de brasileiros letrados em intercâmbios comunicativos de informalidade caracterizados pela aproximação afetiva entre o remetente e o destinatário. Entende-se que os textos de circulação privada, segundo Barbosa (1999), tais como as cartas pessoais, apresentem-se como os mais transparentes, como os mais livres da pressão prescritivista da norma padrão, em relação à explicitação de traços linguísticos da oralidade.

Entender que a produção escrita informal (cartas pessoais) de doze indivíduos unidos por laços familiares e afetivos possa reproduzir, com fidedignidade, a realidade linguística de uma parcela abastada da sociedade brasileira oitocentista e novecentista pode parecer um projeto muito audacioso. Nesse sentido, Silva (1992), ao se referir aos estudos sociolinguísticos com amostras de língua oral (DUARTE, 1995), esclarece e acalma o linguista-pesquisador que se volta para realidades linguísticas pretéritas a fim de estudar uma dada comunidade linguística com base apenas na produção escrita de alguns informantes dela tomados como representantes.

Felizmente a língua é uma propriedade humana relativamente homogênea, entre outros motivos porque, para haver comunicação, é imprescindível que todos tenham acesso pelo menos ao âmago da língua de sua comunidade. Se algum excêntrico resolvesse criar expressões próprias, seria dificilmente compreendido, e essas expressões seriam eliminadas por seleção natural. (SILVA, G., 1992, p.103).

O intuito de tentar captar aspectos da oralidade de informantes cultos, a partir da sua expressão escrita informal, nos séculos XIX e XX, atormenta o linguistapesquisador com a seguinte preocupação: será mesmo possível detectar, em sincronias passadas, traços da oralidade com base na análise da produção escrita de indivíduos letrados? Segundo Aguillar (1998), há a possibilidade de entrever o oral através da escrita, porém, há de se atentar para o fato de que hábitos de escrita também podem transparecer na produção, misturando-se, pois, com os indícios da língua oral.

A presença do oral na escrita é inegável, se intui, e às vezes é possível inclusive demonstrar-se: mas todo discurso é misto, impuro e do mesmo modo que a oralidade pode impregnar certos tipos de escrita, também 
as práticas de escrita podem infiltrar-se na oralidade.? (AGUILLAR, 1998, p.239-240, tradução nossa).

A perspectiva que embasa o estudo linguístico a partir de cartas pessoais é a de que o caráter informal de tais textos evidencie uma produção escrita menos "cuidada" à luz da norma subjetiva ${ }^{8}$ (CUNHA, 1985). Porém, consciente da inquietação que cerca o trabalho com textos escritos a fim de vislumbrar o oral, cabe cercar-se de cuidados em relação à constituição de um conjunto de textos que se aproxime da espontaneidade da fala e que esteja criteriosamente organizado em relação à identificação do perfil sócio-histórico dos remetentes e dos destinatários das missivas. Acredita-se que o elevado nível de escolaridade dos informantes possa ofuscar, mesmo que na informalidade das suas cartas pessoais, traços da oralidade do português, o que reconduz o foco desta análise não para a busca do oral através da escrita, mas para a caracterização da produção escrita informal de indivíduos letrados no Brasil dos séculos XIX e XX.

Movidos pela intimidade dos temas tratados, conforme se observa nos trechos em análise de (06) a (08), os informantes da família Pedreira Ferraz-Magalhães podem evidenciar as escolhas tratamentais feitas no período. Reconhece-se, a partir da leitura dessas missivas familiares, produzidas entre os anos de 1877 e 1948, a história da vida privada de uma família brasileira nascida no Rio de Janeiro que circulou da capital carioca para o interior e por outros espaços sócio-geográficos dentro e fora do Brasil. Uma família religiosa que, apesar dos deslocamentos advindos da pressão social da vida adulta, manteve-se unida pelas cartas ativas e passivas trocadas entre seus membros ao longo das suas vidas. Com base nessas amostras, é possível detectar as redes sócio-familiares das quais participavam seus membros, o comportamento sociolinguístico de uma família cristã na Corte carioca e, ainda, o perfil sociocultural da mulher, sobretudo a mulher religiosa, no início do período republicano do Brasil em transformação.

(6) Carta de João Pedreira do Couto Ferraz, com 51 anos, a sua filha Zélia, com 20 anos: "Tal é o consaço, que me accomette, que devera já estar deitado afim de [ver] si concilio osonno e mesmo porque as 2 horas de amanha pela manhã devo estar já de pé tomando algum alimento e logo apoz descendo a serra da Tijuca, porem o desejo de escrever-te e fingir que estou conversando comtigo são incentivos mais poderosos de que os meios hygienicos para eu não passar tão mal." (Rio de Janeiro, 11.08.1877).

\footnotetext{
"La presencia de lo oral en lo escrito es innegable, se intuye, y a veces puede incluso demostrarse: pero_todo discurso es mixto, impuro, y del mismo modo que la oralidad puede impregnar ciertos tipos de escritura, también los modos escriturarios pueden infiltrarse en la oralidad." (AGUILLAR, 1998, p.239-240.)

8 Segundo Celso Cunha (1985, p.52), “[...] a palavra norma costuma ser empregada em dois sentidos bem distintos: um, correspondente a uma situação objetiva e estatística, fruto da observação; outro, relacionado com uma atitude subjetiva, envolvendo um sistema de valores."
} 
(7) Carta de Jerônimo de Castro Abreu Magalhães, com 46 anos, ao seu filho Jerônimo, com 16 anos. Fazenda Santa Fé:

“(...) Conhecimento profundo do latim é um instrumento precioso para outros mais altos conhecimentos - Mas é tarde Terei mais occasiões de Contigo

Conversar Sé feliz no santo temor de Deus. Meus respeitosos cumprimentos a meo Compadre o Senhor Padre Superior e a teus mestres e acceita a benção de teo Pae e amigo Jeronymo" (Rio de Janeiro, 19.07.1897).

(8) Carta de Maria Rosa, com 70 anos, ao irmão Pe. Jerônimo, com 67 anos:

"Pasei a manhã muito agradavel escrevendo a Você parece que estavas aqui." (La Plata, 01.02.1948).

Acredita-se que as cartas produzidas pela família Pedreira Ferraz-Magalhães, representantes de uma amostra criteriosamente organizada, possa subsidiar estudos sociolinguísticos acerca da produção escrita de brasileiros letrados que viveram em fins do século XIX e na primeira metade do século XX.

\section{Pressupostos teórico-metodológicos: a mudança linguística sob o enfoque dos pressupostos variacionistas}

A intrigante contradição do Estruturalismo Saussureano é a ideia de que, para dar conta da configuração estrutural da língua, é legítima a concepção de língua como um sistema homogêneo, como o domínio da invariância, que exclui a extensão sócio-histórica da análise linguística. Essa incongruência da teorização de Saussure se revela através do Paradoxo Saussureano: como admitir que, para entender o funcionamento interno da língua (langue), deva-se atentar para a expressão do discurso de um único indivíduo (parole) que, por sua vez, somente pode se dar numa situação de interação comunicativa, em um dado momento histórico-social? Sob a perspectiva da Sociolinguística Variacionista de orientação Laboviana, voltam-se os olhares não só para a configuração interna da língua, como previa Saussure (1969), mas também para a sua configuração social, concebendo-a como um sistema movido por uma heterogeneidade ordenada cujas manifestações linguísticas variáveis podem ser descritas e analisadas, nos seus níveis estrutural e social, segundo Weinreich, Labov e Herzog (1968). Visando à elucidação de incoerências, nos estudos saussureanos, entende-se que a abordagem do contexto histórico se faça necessária à reconstrução da história linguística e social, conforme Weinreich, Labov e Herzog (1968) e Labov (1994), com base nas noções de variação e mudança como traços essenciais à estruturação interna das línguas.

Labov (1994) entende as noções de variação e mudança como movimentos constitutivos das línguas humanas, assumindo que a função da linguística histórica é a de detectar as diferenças entre o passado e o presente das línguas. 
Essa detecção pode ser obstaculizada por não ser tão simples inferir quanto o passado foi diferente do presente. Trata-se do paradoxo diacrônico (historical paradox), que motivou Labov a assumir o presente como uma realidade linguística a partir da qual se pudesse entender o passado das línguas. Acredita-se que o fato de a força propulsora da mudança linguística ter atuado no passado legitima a sua influência sobre a realidade linguística sincrônica (atual), como reflexo do princípio norteador da mudança nas línguas humanas - The uniformitarian principle (LABOV, 1994).

Ao admitir que as línguas humanas sejam movidas por variação, potencial que, por sua vez, pode levá-las a uma mudança gradual e paulatina, como entender o seu funcionamento interno pari passu à implementação da mudança estrutural? A Sociolinguística Variacionista, à luz dos estudos de William Labov, passa a se preocupar em estudar a mudança linguística não somente quando já se efetivou na língua, mas também quando ainda está sob a progressão dinâmica da variação no sistema linguístico.

A depreensão do processo de implementação da mudança linguística envolve ainda o esclarecimento das seguintes questões teóricas pensadas por Weinreich, Labov e Herzog (1968): o problema das restrições (constraint problem) - a detecção dos fatores motivadores da mudança linguística; o problema da transição (transition problem) - a análise das etapas pelas quais a língua atravessa, de modo gradual e paulatino, ao se transformar; o problema do encaixamento (embedding problem) - a observação do ajuste da mudança nas matrizes linguística e social; o problema da avaliação (evaluation problem) - a apreciação do falante acerca da mudança linguística e de suas consequências na sua estrutura; o problema da implementação (actuation problem) - a percepção da instauração da mudança linguística a partir da seguinte indagação: por que um dado processo de mudança linguística se instaurou em período e espaço específicos e não em outros momentos e lugares da história da língua? É possível depreender quem, quando e como implementou a mudança?

A busca por compreender o processo de implementação da mudança linguística perpassa pelos estudos em tempo aparente, que se põem a detectar os fenômenos linguísticos variáveis nas distintas faixas etárias dos informantes como a expressão objetiva da língua, em um dado momento histórico-social. Labov (1994) discute a possibilidade de o estudo em tempo aparente evidenciar apenas um processo de variação estável. Esta seria caracterizada pela manifestação das alternâncias de usos linguísticos que se conservam a cada geração de informantes como uma evidência de um processo de gradação etária, não apontando, pois, para um processo de mudança em progresso na língua. A fim de elucidar esse impasse da análise do fenômeno linguístico como um estágio de variação estável (gradação etária) ou como a implementação 
da mudança linguística (mudança em progresso), Labov (1994) instiga a realização de estudos linguísticos que conjuguem os resultados das análises em tempo aparente com as evidências dos estudos em tempo real.

Os estudos em tempo real se caracterizam, conforme teoriza Labov (1994), como análises linguísticas em discretos períodos de tempo (estudos de curta duração) e como estudos linguísticos que envolvem dilatados lapsos de séculos (estudos de longa duração). Ao pensar a produtividade dos estudos linguísticos em tempo real de curta duração, Labov conjectura duas estratégias de depreensão da dinamicidade da variação em relação a formas linguísticas alternantes em processo de mudança linguística. São elas: o estudo de painel (panel study) e o de tendências (trend study). Enquanto este se estabelece através da comparação entre distintas amostras linguísticas de diferentes informantes pertencentes a uma mesma comunidade linguística, aquele consiste na comparação entre amostras linguísticas dos mesmos informantes em um período de tempo entre o recontato dos mesmos informantes, que Labov recomenda ser de, "[...] no mínimo, meia geração (12 anos) e, no máximo, duas gerações (cerca de 50 anos)." (LABOV, 1981, p.177 apud PAIVA; DUARTE, 2003, p.22). A confiabilidade dos estudos de painel (panel study) e de tendências (trend study) depende da rigidez dos critérios de composição da amostra de dados e dos métodos (entrevistas, questionários, tipos de textos) a serem aplicados às análises linguísticas em distintos momentos. Isso quer dizer que, tanto no recontato dos informantes (estudo de painel) quanto na análise do comportamento linguístico de distintas amostras de distintos informantes da mesma comunidade linguística (estudo de tendências), é preciso utilizar os mesmos critérios de seleção dos informantes e as mesmas condições metodológicas de constituição das amostras.

O caráter inovador deste trabalho está na confecção de um estudo de painel (panel study) nos moldes labovianos que se aplique à análise de sincronias passadas: cartas pessoais oitocentistas e novecentistas. Neste texto, o foco recairá sobre os resultados da variação Tu e Você, nas cartas oitocentistas e novecentistas, direcionando a reflexão para a representatividade da categoria social gênero. A análise da expressão (nula ou plena) das formas Tu e Você como sujeitos pronominais se dá com base em cento e setenta cartas familiares trocadas entre os membros de uma mesma família: a família Pedreira Ferraz-Magalhães. Trata-se de cartas seguramente produzidas por brasileiros cultos cujos perfis sociais foram levantados na íntegra por Rumeu (2008) a fim de que se possa assegurar que a pena com a qual se escreveram tais cartas, em fins do século XIX e na primeira metade do XX, historiou, de modo fidedigno, a face brasileira do português. A codificação e a organização dos dados foram conduzidas pelas orientações instrumentais da pesquisa sociolinguística quantitativa de base Laboviana (PAIVA; DUARTE, 2003; MOLLICA; BRAGA, 2004; GUY; ZILLES, 2007). 


\section{O fator social gênero (sexo) em processos de variação e mudança linguísticas}

É interessante refletir sobre as principais constatações de alguns estudos sobre processos de variação linguística que permitem evidenciar a influência da variável gênero (sexo) na escolha de uma dada forma variante. Nesses estudos, confirma-se a hipótese Laboviana (LABOV, 1990) de que, nos processos de variação, as mulheres tendem a usar as formas que refletem a norma padrão, desviando-se, pois, das variantes linguísticas socialmente estigmatizadas.

Trabalhos sociolinguísticos que visam depreender a progressão da mudança linguística mostram que nem sempre é possível evidenciar uma clara polarização entre o comportamento linguístico de homens e mulheres e o uso de variantes desprestigiadas e prestigiadas. O paradoxo do gênero, segundo Labov (1990), estabelece-se a partir da seguinte dinâmica: em processos de variação linguística, como dito acima, as mulheres tendem a se voltar para a norma padrão, mostrandose mais conservadoras ao evitarem a estigmatização. Inverte-se a situação em processos de mudança linguística. Nesses casos, as mulheres tendem a introduzir a forma "não padrão", mostrando-se mais inovadoras e os homens, conservadores. No entanto, ao estudar a estratificação social do inglês de Nova York, com base na análise da realização retroflexa do [r] pós-vocálico (card), Labov (1966 apud PAIVA, 2004) observou que as mulheres optaram pela implementação da forma socialmente prestigiada: a pronúncia retroflexa do [r] pós-vocálico. Ao estudar a centralização de /ay/ e /aw/ em Martha's Vineyard, Labov constata que os homens lideraram o processo de mudança, o que o levou a admitir que a distinção sexual (gênero masculino versus gênero feminino) está sujeita "[...] a uma postura expressiva que é socialmente mais apropriada para um sexo do que para outro." (LABOV, 2008, p.348-349).

Redirecionando o foco para os estudos de fenômenos morfossintáticos, passa-se à exposição de resultados de análises linguísticas nas quais o gênero se mostrou relevante nas comunidades linguísticas de Eskilstuna (Suécia), Montreal (Canadá) e do Brasil. Laberge (1977 apud PAIVA 2004) pesquisa a alternância entre os pronomes nous (nós) e on (a gente) do francês oral de Montreal (Canadá) - Nous allons au cinema/On va au cinema ${ }^{9}$. Nesse processo de variação, as mulheres preferiram o pronome licenciado pela norma padrão, isto é, elegeram a forma socialmente prestigiada (nouss). Ainda em relação à variação pronominal, apresentam-se os resultados de Paredes Silva (1996) sobre o emprego variável das formas Tu e Você na variedade carioca do PB falado. A autora constata que o uso do Tu em desarmonia sintática com o verbo na terceira pessoa do

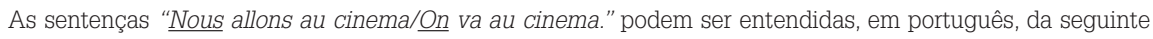
forma: "Nós vamos ao cinema"/"A gente vai ao cinema." 
singular (Tu quer uma cerveja?) é mais produtivo na fala dos homens cariocas, com .57 de peso relativo. As mulheres parecem ter optado por não se exporem a uma construção sintática tão seriamente rechaçada pela norma gramatical: o emprego do Tu sem concordância verbal. A influência da variável gênero também pode ser observada em um processo de mudança linguística, tal como o de concordância verbal, no qual a presença da concordância, estratégia menos marcada socialmente, é preferida pelas mulheres, como evidenciado por Naro e Scherre (2010 apud SCHERRE; YACOVENCO, 2011), ao compararem as amostras de fala do corpus PEUL 1980 com as do corpus PEUL 2000².

Omena (1996) analisa a alternância nós e a gente como sujeito pronominal no português falado pelos cariocas. Os homens, ao optarem pelo nós, mostraramse conservadores, ao passo que as mulheres, ao preferirem o a gente, lideraram o processo de mudança ao assumirem uma postura mais inovadora. Entretanto, não se pode afirmar com veemência que o emprego de nós evidencia o "padrão" e o a gente, o "não padrão", pois tais formas pronominais variantes não são socialmente estigmatizadas. Acredita-se ser mais coerente, portanto, optar por tratar as formas variáveis nós e a gente como forma conservadora, aquela já existente na língua, e como forma inovadora, a que surgiu a posteriori no sistema linguístico. Não necessariamente as formas conservadoras e inovadoras devem estar vinculadas à norma padrão e à norma não padrão, respectivamente.

Zilles (2005) estuda a produtividade do pronome a gente no PB falado em Porto Alegre, entendendo-a como mudança implementada de baixo para cima (change from below) (LABOV, 1994). Em relação ao gênero, a autora constatou que as mulheres conduziram o processo de mudança, à exceção do grupo de maior nível de escolaridade, em que a distinção em relação ao gênero foi neutralizada. Segundo a autora, tal resultado pode sugerir o surgimento de uma avaliação social negativa da nova forma (a gente) em consonância com o comportamento da mulher cujo nível de escolaridade é elevado. Ainda que o a gente seja posterior ao nós, daí o seu caráter inovador, pode ter assumido, segundo a autora, uma avaliação social negativa pela camada mais escolarizada da sociedade brasileira.

Raumolin-Brunberg (2005) examina como a forma de segunda pessoa do pronome objeto YOU passou a ser usada na função de sujeito no inglês escrito entre os séculos XIV e XVIII (1350 - 1710). Trata-se de uma mudança morfossintática do sujeito YE para o YOU, que conviveram na produção escrita de 60\% dos informantes entre os anos 1520 e 1539, considerado o rápido período de difusão das formas variantes Ye e You. O YOU na função de sujeito é introduzido

10 Amostras de fala gravadas pelo Programa de Estudos do Uso da Língua (PEUL). 
no século XIV, espraiando-se a partir de 1480 e implementando-se a partir de 1560. A autora admite se tratar de uma mudança vinda de baixo em termos de consciência social (change from below) (LABOV, 1994) conduzida pelas mulheres no seu período de difusão.

Scherre e Yacovenco (2011) propõem duas esclarecedoras generalizações sobre o efeito do gênero em processos de variação e de mudança linguísticas, tomando por base a alternância $\mathbf{T u}$ /Você; a alternância do imperativo vinculado ao indicativo (olha, diz, vem), do imperativo relacionado ao subjuntivo (olhe, diga, venha) e do fenômeno variável de concordância de $3^{a}$ pessoa verbal.

(1) Traços linguísticos marcados, no sentido de serem menos dependentes das relações interacionais ou mais frequentes ou mais aceitos socialmente, tendem a ser favorecidos pelas mulheres: o tu como índice de identidade geográfica, o imperativo associado ao indicativo em contatos dialetais, a presença da concordância verbal.

Generalização: em configurações menos marcadas - e não necessariamente mais prestigiadas - as mulheres estão à frente na variação ou na mudança.

(2) Traços linguísticos mais marcados, no sentido de serem mais dependentes das relações interacionais ou menos frequentes ou menos aceitos socialmente, tendem a ser favorecidos pelos homens: o tu como índice de interação solidária; o imperativo associado ao subjuntivo em contatos dialetais; a ausência de concordância verbal.

Generalização: em configurações mais marcadas - e não necessariamente menos prestigiadas - os homens estão à frente na variação ou na mudança. (SCHERRE; YACOVENCO, 2011, p.138-139, grifo nosso).

Sundgren (2001) discute o fato de as mulheres da Eskilstuna (Suécia) empregarem mais a linguagem de prestígio que os homens. A autora defende que homens e mulheres assumem diferentes tipos de ocupação, o que pode gerar as diferenças de usos em relação à forma padrão. A mulher tem de usar as formas voltadas para a língua padrão para que o seu discurso adquira prestígio. O homem, por sua vez, não necessita usar a norma padrão para adquirir prestígio no interior da comunidade sueca de Eskilstuna. O discurso masculino é assumido como norma, ainda que essa norma nem sempre corresponda à norma padrão. O valor atribuído ao discurso masculino, a que Sundgren se refere, dialoga com a noção de prestígio encoberto (covert prestige) (LABOV, 2008). Enquanto o homem está mais propenso a se envolver em interações comunicativas em distintas esferas da sociedade, a mulher fica restrita ao exercício de atividades específicas no âmbito doméstico. Nesse sentido, a expressão linguística masculina goza de um prestígio encoberto no interior da comunidade linguística de Eskilstuna (Suécia). 
Também em relação ao objeto de estudo desta investigação, fazse necessário explicar o que se entende por comportamento linguístico conservador VS. inovador, além de se relativizar o conceito de "padrão" e "não padrão." O emprego preferencial do Tu, estratégia de referência à segunda pessoa do discurso mais antiga no sistema pronominal do $\mathrm{PB}$, proveniente do latim vulgar Tu (nominativo) ${ }^{11}$, é entendido como um uso linguístico conservador. Por outro lado, a preferência pelo Você, estratégia pronominal inserida, gradual e paulatinamente (Vossa Mercê $\rightarrow$ Você), no sistema pronominal do PB, seria considerada como expressão de um comportamento linguístico inovador.

Além disso, pela produtividade de Você nas cartas de pessoas ilustres no século XIX, conforme discutido nas considerações iniciais deste trabalho, não se pode dizer que, no Brasil, a variante inovadora Você carrega um estigma social. Assim sendo, não pode ser considerada como uma variante "não padrão" stricto sensu, como previa Labov (1990). Faz-se necessário rediscutir esse conceito de variante "não padrão" em relação ao escopo deste trabalho. O processo gradual e paulatino de gramaticalização de Vossa Mercê leva ao surgimento do Você, que passa a ser usado no mesmo domínio funcional que o Tu (genuíno pronome de segunda pessoa). O termo "não padrão" só poderia, pois, ser aplicado à forma Você no seguinte sentido: o Você é uma forma pronominal que, nascida de uma necessidade de delimitação do espaço social português através do estabelecimento de formas específicas para identificar a rígida hierarquização social portuguesa (Vossa Mercê para o rei português, no século XVI) é posterior ao Tu. O Você alcança o status de autêntico pronome de segunda pessoa do discurso (sujeito de referência determinada), chegando, até mesmo, a se comportar como uma estratégia de indeterminação do sujeito (sujeito de referência indeterminada ou arbitrária) $^{12}$.

Diante das considerações tecidas sobre a variável gênero (sexo) em função de resultados de estudos sobre fenômenos linguísticos variáveis nas comunidades linguísticas de Eskilstuna (Suécia), de Montreal (Canadá) e do Brasil, é possível admitir que as performances linguísticas de homens e mulheres são motivadas pelos papéis sociais que assumem num dado contexto sócio-histórico. Nesse sentido, os resultados das pesquisas sobre fenômenos linguísticos em processo de variação e mudança comungam de um aspecto em comum: as mulheres mostram-se mais sensíveis ao prestígio social atribuído às formas linguísticas. Neste estudo, a partir da produção escrita de informantes

1 Segundo Maurer Jr. (apud ILARI, 2002), a segunda pessoa pronominal (singular) assumia, no latim vulgar, as seguintes formas: Nominativo: $\boldsymbol{t u}$; Genitivo/Dativo: $\boldsymbol{t i} / \mathbf{t i b i}$; Acusativo: $\boldsymbol{t e}$.

12 Observe-se o emprego do Você como estratégia de indeterminação do sujeito em amostra do PB oral examinada por Duarte (1995, p.111): "Você, quando você viaja, você passa a ser turista. Então você passa a fazer coisas que você nunca faria no Brasil." 
cariocas (homens e mulheres), pretende-se depreender a influência da variável gênero no processo de implementação do Você no quadro pronominal do PB oitocentista e novecentista.

Os resultados do estudo de painel voltado para a diacronia: o comportamento linguístico dos homens e das mulheres da família Pedreira Ferraz-Magalhães nas eras oitocentista e novecentista do português

Considerando que este estudo visa à depreensão da variação entre as formas Tu e Você como estratégias de referência ao interlocutor e à compreensão do processo de inserção do Você no quadro pronominal do PB, entende-se que se faça necessário focar o comportamento linguístico do indivíduo em distintos momentos da sua trajetória de vida, visando detectar a progressão da mudança linguística.

O estudo de painel dos missivistas do gênero masculino Dr. Pedreira, Fernando e Jerônimo os evidenciou como informantes que selecionaram o Tu pronominal para a referência ao sujeito de segunda pessoa do discurso, como é possível observar no gráfico 01.

Gráfico 1 - Emprego de "Você" na posição de sujeito em cartas pessoais: painel dos homens da família Pedreira Ferraz-Magalhães ao longo de suas vidas

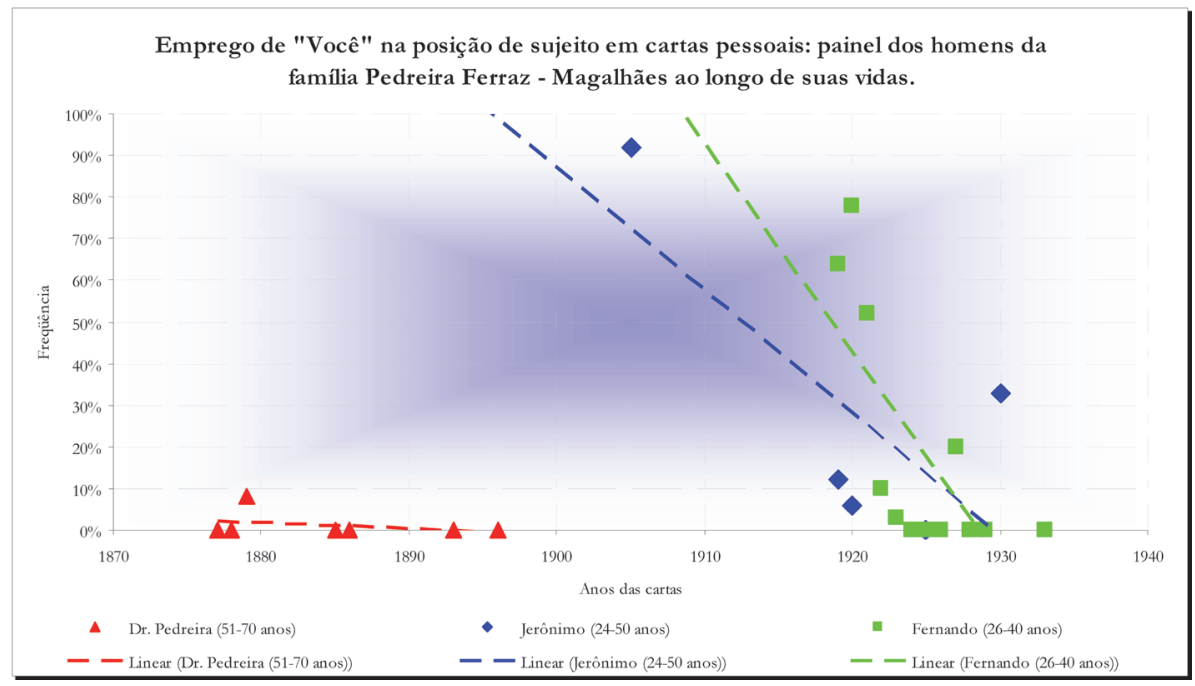

Fonte: Elaboração própria. 
A análise do comportamento dos homens da família Pedreira FerrazMagalhães, com base na dispersão expressa no gráfico 01, evidencia uma maior produtividade de Você entre os anos de 1900 e 1920 nas cartas dos dois mais jovens. Nesse período, os irmãos Fernando e Pe. Jerônimo, que, na maior parte das vezes, preferiram o Tu em suas missivas, mostraram-se, quando jovens, mais propensos a empregar o Você, como se observa em (09) e (11). O idoso Dr. Pedreira, com um baixíssimo nível de aplicação do Você nas suas cartas, mostrou-se, em fins do XIX, propenso a deter o avanço da direção histórica da mudança linguística que, por sua vez, sugere a inserção do Você como um pronome de segunda pessoa do discurso, como se constata em (09). A linha descendente delineada no gráfico de dispersão aponta para a diminuição do uso de Você nos anos 20-30 entre os homens dos Pedreira Ferraz-Magalhães.

(9) Carta do Dr. Pedreira, com 51 anos, missivista IDOSO, a filha Zélia, com 20 anos: "Escrevo te para contar te que fiz bôa viagem e achei todos com saúde, tendo noticias do Zuzú. Bem desejo que continues a passar bem de tua dupla existencia, referindo me ao teu marido e tríplice pelo fructo abençoado e proximo do teu feliz consorcio. [...] Convem que Vocês d'ahi escrevão cartas a elle comprimentando pelo seu anniversario." (Rio de Janeiro, 05.02.1877).

(10) Carta de Jerônimo, com 24 anos, missivista JOVEM, ao irmão Fernando, com 12 anos:

"Que alegria quando eu voltar Padre para o Brasil, não é? Mamãe, Papae Pedreira, todos ficarão contentíssimos, não achas? Eu penso que você deve ajudar minha $1^{a}$ Missa junto com Bebê." (Paris, 15.10.1905).

(11) Carta de Fernando, com 26 anos, missivista JOVEM, ao irmão Jerônimo, com 38 anos: "[...] Soube por meio de tia Mimi, residente por algum tempo aqui em Friburgo, que vôcê virá para as ferias." (Rio de Janeiro, Friburgo, 06.11.1919).

O Dr. Pedreira mostrou, em um intervalo temporal de dezenove anos, um comportamento linguístico estável voltado para a preferência pelo Tu pronominal, ao fazer referência aos filhos. Seguindo esse comportamento linguístico, vêm os seus netos, os informantes Fernando e Pe. Jerônimo que, em lapsos temporais de quatorze e vinte e seis anos, respectivamente, demonstraram estabilidade linguística no que se refere ao uso das formas Tu e Você para tratar os irmãos. Ao preferirem o Tu, na fase adulta, os homens da família Pedreira Ferraz-Magalhães sugerem um movimento voltado para a retenção da direção histórica da mudança linguística com o menor emprego do inovador Você nas missivas em análise.

O gráfico de dispersão relativo às mulheres da mesma família Pedreira FerrazMagalhães projeta comportamento oposto: ascendência contínua do traçado relativo à forma Você entre os anos de 1925 a 1945. 
Gráfico 2 - Emprego de “Você" na posição de sujeito em cartas pessoais: painel das mulheres da família Pedreira Ferraz-Magalhães ao longo de suas vidas

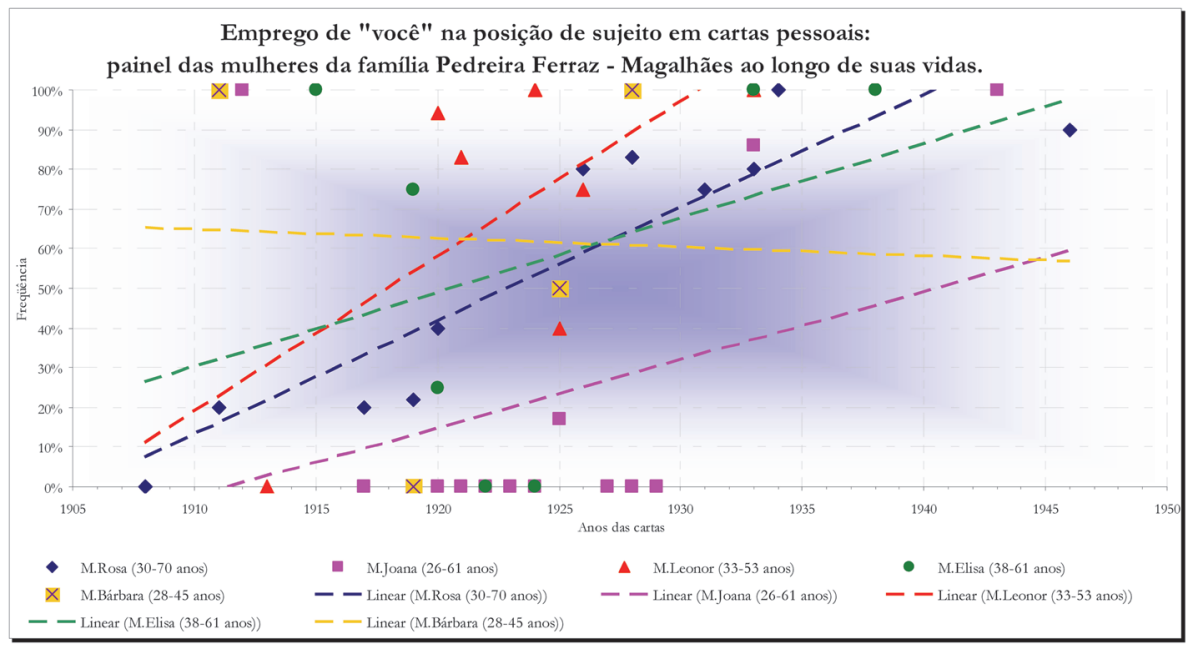

Fonte: Elaboração própria.

A partir da análise do gráfico 02, observa-se que a produtividade variável do Você como sujeito de segunda pessoa do discurso parece sinalizar que a sua implementação se deu, de modo mais transparente, a partir do segundo quartel do século XX (entre os anos 20 e 30), nas cartas pessoais femininas dos Pedreira Ferraz-Magalhães. Com relação ao encaixamento dessa mudança linguística em progresso na matriz social (embedding problem), entende-se que as mulheres parecem ter impulsionado o processo de mudança em progresso na língua, ao elegerem o Você como estratégia de referência ao interlocutor no PB.

Há de se considerar, contudo, um comportamento diferenciado entre as mulheres da família. Verificou-se que quatro delas mostraram-se instáveis (Maria Bárbara, Maria Elisa, Maria Joana e Maria Rosa) e somente uma mulher mostrou-se estável (Maria Leonor) no que se refere ao emprego das formas Tu e Você. Em relação ao grupo de mulheres instáveis, constatou-se que duas delas preferiram o inovador Você (Maria Bárbara e Maria Rosa) e as outras duas adotaram o conservador Tu (Maria Joana e Maria Elisa) nas cartas em análise. A informante Maria Leonor, por sua vez, delineou uma curva de estabilidade em relação a sua preferência pelo inovador Você. As mulheres Maria Bárbara, Maria Rosa e Maria Leonor, ao elegerem o Você para se referirem aos irmãos, parecem se conduzir a favor da direção histórica da mudança linguística: a implementação do Você no quadro pronominal do PB. 
Uma visão panorâmica do comportamento das mulheres no decorrer de suas vidas, conforme o gráfico 02, evidencia o período dos anos 30 do século XX como o momento em que as informantes idosas Maria Elisa, Maria Joana, Maria Leonor e Maria Rosa alavancam o emprego do Você nas cartas em análise, como se constata de (12) a (18). A adulta Maria Bárbara, entre os anos 25 e 30 do século XX, prefere o Você para tratar os irmãos na intimidade das cartas em análise, como se nota em (12). Na verdade, observa-se que as jovens Bárbara e Joana utilizam categoricamente o Você, ao se referirem aos irmãos, como se verifica em (13) e (14). Na fase adulta, percebe-se que tais informantes oscilam entre o Tu e o Você, ao passo que, na velhice, Maria Elisa, Maria Joana, Maria Leonor e Maria Rosa voltam-se ao uso do Você, como se nota de (15) a (18).

(12) Carta de Maria Bárbara, com 43 anos, missivista ADULTA, ao irmão:

"Não vale a pena eu escrever ao Senhor Padre Yábar, pois elle disse-me que está prompto para escrever o que você quizer, você é que deve escrever-lhe dizendo o que quer (ou sobre o que quer que elle escreva, sua direção é Egreja do Bom Pastor." (São Paulo, 19.04.1926).

(13) Carta de Maria Bárbara, com 28 anos, missivista JOVEM, ao irmão Jerônimo, com 30 anos:

"Temos a mesma missão querido Irmão a de salvar almas eu aqui dentro de meu amado claustro e você pelo mundo enteiro aonde a obediencea lhe mandar, que missão tão soblime!!! não é? [...] Soube que tem tenção de pedir para mudar de casa pela por te achar peor dos ouvidos; se quer meu parecer, não pessa isto pois o melhor é nada pedir e nada recusar;" (São Paulo, 25.06.1911).

(14) Carta de Maria Joana, com 26 anos, missivista JOVEM, ao irmão, em 16 de janeiro de 1912:

"Então, como se decidiu logo a sua partida! irá até ao Pará? Eu escrevo a Isa, pelas Irmãs nossas que vão no mesmo vapor que Você e das quaes uma vae até ao Pará. Peço a Nosso Senhor que Você faça muito boa viajem ... poderá celebrar a bordo?"

(15) Carta de Maria Elisa, com 56 anos, missivista IDOSA, a Jerônimo, com 52 anos: "[espaço] Adeus, meu Jeronymo; [espaço] A Superiora da Santa Casa não é Almeida Magalhães como lhe disse em minha ultima carta; é Magalhães Barbalho, conhecida em Barbacena por [Irmã] Helena. Quando me escrever diga-me si Você a conhece, sim? e mande-lhe um pequeno conforto na cruz que carrega;" (Rio de Janeiro, Friburgo, 07.02.1933).

(16) Carta de Maria Joana, com 60 anos, missivista IDOSA, ao irmão Pe. Jerônimo, com 65 anos:

"Bem, meu irmão, gostaria que Você me escrevesse 1 vez por mês, agora que o podemos fazer confidencialmente, aceita?" - Qualquer coisa a Provincial resolva sobre mim, Você saberá logo." (Bahia, 18.08.1946). 
(17) Carta de Maria Leonor, com 53 anos, missivista IDOSA, a irmã Maria Elisa, com 56 anos:

"Eu vou indo, bastante constipada, é coisa passageira. Á Reverenda Madre Provincial tem vindo me ver. Que contente em Você estar em Nova Friburgo e Nenê estará em São Paulo?" (Tamarineira, Pernambuco, 07.03.1933).

(18) Carta de Maria Rosa, com 70 anos, missivista IDOSA, ao irmão Jerônimo, com 67 anos:

“Já chegou o Padre Ceriale preguntou por Você Nossa Madre te manda lembranças o mesmo Irmã Maria Rosa - e Irmã Maria Agustinha, (a do gallinheiro) Quando acabaram as hostias que Você consagrou, não pude deixar de chorar - por ahi Você vê minha amizade por meu irmão. Recebe lembranças de Don Oreste Dona Agusta e do pobre quintero Don Juan. Quando visite o tumulo de nossa santa mãe não te esqueças de pedir pelas minhas intenções." (La Plata, 01.02.1948).

Embora a forma Você represente a forma "invasora", "inovadora" que passa a concorrer com o Tu no quadro pronominal do PB, é uma forma de prestígio, deixando de figurar, no Novecentos, como uma forma exclusiva da elite tratar a própria elite - conforme Soto (2001, 2007), Lopes e Machado (2005), Rumeu (2008), Lopes et al. (2009) e Pereira (2012) -, espraiando o seu campo funcional por toda a comunidade linguística, desvinculada de estigmatização social.

\section{A variação 'Tu'/'Você' na Família Penna nas eras oitocentista e novecentista do português}

As considerações acerca da variação entre as formas Tu e Você tecidas por Pereira (2012), com base na análise de cartas amorosas e familiares da família Penna, dialogam com os resultados obtidos por Rumeu (2008) para a família Pedreira Ferraz-Magalhães. A família Penna é proveniente de Minas Gerais (mais especificamente das cidades de Santa Bárbara, Sabará e Barão dos Cocaes), mas se fixou no Rio de Janeiro. Dentre as cento e quarenta e nove cartas analisadas por Pereira (2012), oitenta e sete delas são cartas familiares, direcionadas a Affonso Penna Jr. por Affonso Penna (pai), por Álvaro Penna, por Edmundo Veiga, por Manuel Penna (tio), por Maria Guilhermina Penna (mãe) e sessenta e duas delas são cartas amorosas, trocadas entre os casais Afonso Penna e Maria Guilhermina Penna e Affonso Penna Júnior e Marieta Penna. Os subgêneros textuais cartas amorosas e cartas familiares se mostraram significativos para a compreensão da variação entre as formas Tu e Você, em fins do XIX e no século XX. Enquanto, nessas missivas, observa-se a expressão de um processo de variação estável entre as formas relacionadas a Tu (P2) e a Você (P3), com índices percentuais de 59\% e 41\%, respectivamente, naquelas, o 
Tu prevalece sobre o Você $\mathbf{e ̂}^{13} \mathrm{com}$ um índice percentual de 95\%. Como legítimos representantes da família mineira, os Penna representam o subsistema tu você, em consonância com a descrição proposta por Scherre et al (2009)14, distanciando-se da realidade contemporânea de Minas Gerais na qual o Você e variações (ocê, cê) prevalecem hoje em dia.

Ao contrapor o comportamento linguístico dos homens ao das mulheres da família Penna em relação à produtividade de Tu e Você na posição de sujeito, Pereira (2012) constata que os homens (Alvaro e Manuel) preferiram quase categoricamente o Tu e os missivistas (Edmundo e Afonso) que preferiram o Você, fizeram-no, assim como Alvaro e Manuel, como forma de mitigar assuntos ameaçadores à face do interlocutor. Assim sendo, a autora assume que o Você é produtivo em contextos cuja motivação é pragmática, como se observa de (19) a (23), a partir de uma ordem consubstanciada em um pedido.

(19) Carta de Manuel Penna a Affonso Penna Júnior, em 05 de novembro de 1906: "Podia tambem escrever a seo Pae, e Dr João Pinheiro porem entendo não ve necessario só basta que você si interessou. Como sabes para a reorganização da Fabrica é necessaria a mia efficaz intervenção".

(20) Carta de Manuel Penna a Affonso Penna Júnior, em 24 de agosto de 1909: "(...) não tenhas mandado o que me dissestes doaria a Camara para ser collocada no lugar de honra seria bom que no dia 7, voce vissi e não podendo talvez 0 Amarilio com algum companheiro que [pudessi] discursar e fazer propaganda eu mandaria a condução."

(21) Carta de Edmundo Veiga a Affonso Penna Júnior, em 19 de maio de 1911: "Irmão amigo, Estão feitas as transferencias das acções da Mercantil para seu nome, podendo Você fazer a entrada do dinheiro ahi (refiro-me á $5^{a}$ chamada), pedindo ao José Pedro que comunique ao Banco o pagamento feito."

(22) Carta de Affonso Penna a Affonso Penna Júnior, em 13 de março de 1907:

"Qualquer dia destes enviarei procuração para Você me representar na reunião de credores do Mingo."

13 Tal fato dialoga com as considerações do trabalho de Lopes, Marcotulio e Rumeu (2011) acerca da variação entre as formas $\mathbf{T u}$ e Você em bilhetes amorosos, a partir do qual se observou que $\mathrm{O}$ Tu se fazia mais produtivo nos bilhetes trocados entre a missivista e o amante, ao passo que o Você foi a estratégia preferida pela informante, ao se dirigir ao marido no PB escrito de inícios do século XX.

14 Scherre et al. (2009) correlacionam as formas pronominais Tu e Você com os padrões verbais de concordância ( $2^{\mathrm{a}}$ e $3^{\mathrm{a}}$ pessoas do discurso), chegando a compor um quadro com seis subsistemas tratamentais na posição de sujeito, em função da produtividade assumida pelas regiões do Brasil. Os seis subsistemas tratamentais são os seguintes: Subsistema I: Predomínio de Você nas regiões Centro-Oeste, Sudeste, Sul e Nordeste; Subsistema II: Predomínio de Tu com concordância muito baixa nas regiões sul e norte; Subsistema III: Equilíbrio de Tu/Você com concordância muito baixa com o Tu; Subsistema IV: Predomínio de Tu com concordância média com o Tu; Subsistema V: Uso variável de Você/Tu ou Tu/Você sem concordância; Subsistema VI: Tu/Você ou Você/Tu com concordância médio-baixa. 
(23) Carta de Affonso Penna a Affonso Penna Júnior, em 20 de abril de 1907:

"Avise me com antecedencia o dia que Você marcar para sahida de B. Hte. Você deve convidar o Neca para vir consigo, reforçando a carta que vou escrever lhe nesse sentido."

Por outro lado, a servil e culta, conforme interpretado por Pereira (2012), Maria Guilhermina, de quem mais cartas femininas há nos corpora da família Penna, opta pelo Você nos mesmos domínios funcionais do Tu, ou seja, nenhum dado do Você por ela utilizado é pragmaticamente motivado, como se nota em (24) e (25). Acrescente-se a isso o fato de a missivista, na sua produção escrita de quase trinta anos, ter optado, na sua velhice, pelo Você, desde 1908 (com 55\% de Você) até 1926, (com 100\% de Você), conforme se observa no gráfico 3. Tal comportamento é muito similar aos das missivistas Maria Elisa, Maria Joana e Maria Rosa da família Pedreira Ferraz-Magalhães que, na velhice, também preferiram o Você no mesmo domínio funcional do Tu: na referência ao sujeito de $2^{a}$ pessoa do discurso.

Gráfico 3 - A variação entre as formas Tu e Você na posição de sujeito na produção escrita de Maria Guilhermina Penna, esposa do Presidente Afonso Penna, ao longo de quase 30 anos (1898 - 1926) em que escreve ao filho Afonso Penna Júnior

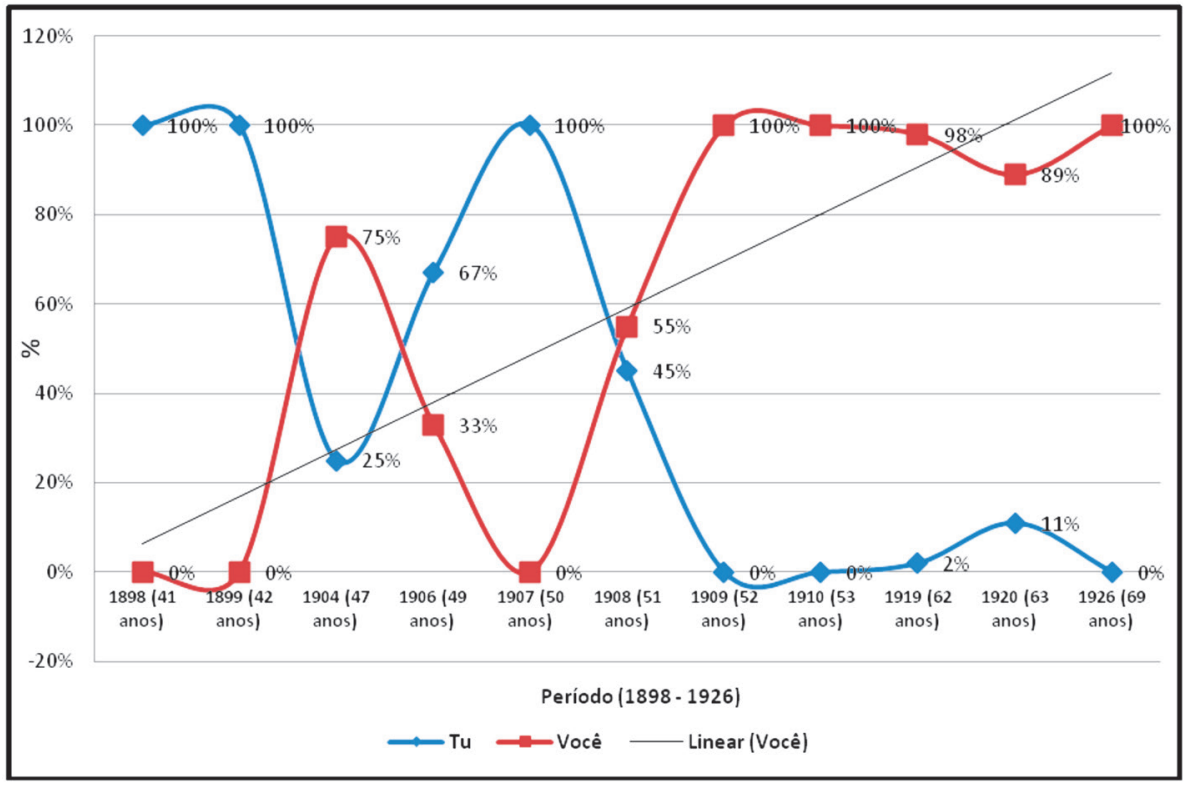

Fonte: Pereira (2012, p.109). 
(24) Carta de Maria Guilhermina Penna a Affonso Penna Júnior, em 23 de setembro de 1919:

"Querido Filho Tenho tido noticias suas, não tenho escrito porque sei que não tens tempo para responder. Sinto bem você não ter mais calma para fazer o seu trabalho, não se alimentar bem e com socego. Agora você deve estar mais tranquillo e mais contente com a presensa de Marieta e filhinhos. [...] O dinheiro que você, mandou para o Salvador ir tirando todos os mezes só restam 800\$ é preciso você mandar o das meninas e 200\$ para pagar a pensão do convento até Dezembro."

(25) Carta de Maria Guilhermina Penna a Affonso Penna Júnior, em 13 de abril de 1926: "Achei que você foi muito depressa tomar conta do serviço devia ter esperado ficar mais forte. [...] Você tem mandado o dinheiro d'ella? Ella não se esquece de vocês."

A análise do painel das mulheres da família Pedreira Ferraz-Magalhães, assim como a análise do percurso da produção escrita de Maria Guilhermina Penna ao filho por quase trinta anos sugere as mulheres, nas eras oitocentista e novecentista do PB, mais dinâmicas que os homens na condução da direção histórica da mudança em relação à inserção do Você no quadro pronominal (change from above).

\section{Sintetizando: a relevância da categoria social gênero para a depreensão da variação 'Tu'/'Você' nas eras oitocentista e novecentista do português brasileiro}

Considerando os resultados da análise sociolinguística acerca da variação Tu/Você nas cartas dos Pedreira Ferraz-Magalhães, vislumbrados através dos gráficos 1 e 2, interpreta-se, respondendo a primeira questão proposta neste trabalho, o gênero como uma categoria social propulsora da inserção do Você no sistema pronominal do PB. A divergência de comportamentos de homens e mulheres, tanto da família Pedreira Ferraz-Magalhães, como da família Penna, consubstanciada na preferência dos homens pelo Tu e na opção das mulheres pelo Você, conduz a outra questão: qual(is) foi(ram) a(s) motivação(ões) social(is) para a implementação do inovador Você no discurso feminino escrito informal das mulheres de ilustres famílias brasileiras?

Labov (2008), ao pensar os padrões sociolinguísticos, admite que, na verdade, a distinção sexual está correlacionada ao tipo de interação social estabelecida entre os falantes no cotidiano linguístico.

Seria um grave erro formular o princípio geral de que as mulheres sempre lideram o curso da mudança linguística. A centralização de /ay/ e / aw/ em Martha's Vineyard foi encontrada principalmente em falantes 
masculinos; as mulheres aqui mostraram uma tendência muito mais fraca. [...] A generalização correta, então, não é a de que as mulheres lideram a mudança linguística, mas sim que a diferenciação sexual da fala frequentemente desempenha um papel importante no mecanismo da evolução linguística. [...] A diferenciação sexual com que estamos lidando depende claramente de padrões de interação social na vida diária. (LABOV, 2008, p.347-348).

Em consonância com o pensamento laboviano, apresenta-se a perspectiva de Fernández (1998), segundo a qual a análise da motivação para as mulheres se mostrarem mais sensíveis à norma padrão requer que se separe a noção de sexo da concepção de gênero sociocultural. O autor propõe as seguintes questões:

\begin{abstract}
Mas de onde nasce essa tendência feminina de seguir os modelos de prestígio? Por que em muitas culturas se espera que a mulher ajuste sua conduta sociolinguística a um cânone ou às referências de prestígio? Por que os usos linguísticos que se consideram característicos das mulheres ou dos homens têm a ver diretamente com o seguimento ou o abandono de uma norma? A maior parte das respostas que se têm dado a estas questões tem a ver com uma interpretação sociocultural do sexo, quer dizer, estão relacionadas com o que na bibliografia anglo-saxã se chama 'gênero', que, por sua vez, em nada coincide com o conceito de "gênero" como gênero gramatical. O gênero sociocultural se opõe ao sexo tanto quanto o sexo é uma característica biológica que é dada praticamente desde o momento da concepção do novo ser, enquanto o gênero assume uma dimensão sociocultural que o indivíduo adquire ao ser socializado. Tais conceitos, todavia, têm limites confusíssimos e contaminados de problemas, dado que o sexo mesmo é parte indissociável do gênero. ${ }^{15}$ (FERNANDÉZ, 1998, p.38, tradução nossa).
\end{abstract}

Assim sendo, a resposta à indagação acerca da motivação social para as mulheres da família Pedreira Ferraz-Magalhães terem implementado o Você, que, por sua vez, coaduna-se com a segunda questão proposta neste trabalho acerca do papel social de homens e mulheres, passa pela diferenciação entre sexo e gênero sociocultural, isto é, passa pela compreensão do perfil sócio-histórico da mulher no Brasil oitocentista e novecentista.

15 "Pero, ¿de dónde nace esa tendencia femenina a seguir los modelos de prestigio? ¿Por qué en muchas culturas se espera que la mujer ajuste su conducta sociolingüística a un canon o unos referentes de prestigio? ¿Por qué los usos lingüísticos que se consideran característicos de las mujeres o de los hombres tienen que ver directamente con el seguimiento o el abandono de una norma? La mayor parte de las respuestas que se han dado a estas cuestiones tienen que ver con una interpretación sociocultural del sexo, es decir, están relacionadas con lo que en la bibliografía anglo-sajona se llama gender 'genero', que a su vez en nada coincide con el concepto de "genero" como categoría gramatical. El género sociocultural se opone al sexo en tanto en cuanto el sexo es una característica biológica que viene dada prácticamente desde el momento de la concepción del nuevo ser, mientras el género es una dimensión sociocultural que el individuo adquiere al ser socializado. Tales conceptos, sin embargo, tienen unos límites borrosísimos y plagados de problemas, dado que el sexo mismo es parte insoslayable del género." (FERNÁNDEZ, 1998, p.38). 
Nesse sentido, observou-se que, em fins do século XIX e na primeira metade do século XX, apesar de a mulher resguardar uma incondicional subserviência à estrutura de família patriarcal, cabe a ela instaurar a harmonia de um lar cristão, principalmente no grupo em questão. Considerando, em termos linguísticos, a responsabilidade de a mulher-mãe da elite brasileira ensinar aos filhos as primeiras letras, impõe-se a ela um comportamento educativo voltado para o recato. Assim sendo, a preferência pelo emprego do Você nas cartas trocadas entre os irmãos da família Pedreira Ferraz-Magalhães se dá como uma estratégia mais neutra, ou seja, como uma forma menos invasiva de fazer referência ao interlocutor. Uma vez que a história da mulher - ao menos nesse período analisado - é marcada pela sua subserviência ao homem, sendo a ela negado o direito de expressão de suas próprias ideias, a opção pelo Você é condizente com esse perfil social de submissão, isto é, "com uma conduta específica", nos termos de Chambers e Trudgill (1980 apud FERNÁNDEZ, 1998), voltada para o recato da subordinação a uma estrutura familiar patriarcal mais acentuada até o século XIX, conforme Samara (2004).

Chambers y Trudgill, com um critério que parte do conceito sociocultural de gênero, explicam a tendência de as mulheres seguirem os modelos de pretígio mediante aos seguintes argumentos: a falta de um lugar destacado na sociedade leva as mulheres a necessitarem marcar seu status social mediante uma conduta específica; por outro lado, a falta de coesão das mulheres nas redes sociais as obriga a deparar-se mais frequentemente com situações de formalidade, isto é, o lugar do homem nos intercâmbios sociais permite que considerem como de escassa formalidade muitas situações que as mulheres interpretam como mais formais; finalmente, a educação pode levar as mulheres a desempenhar o que se considera <<sua >> função social seguindo umas normas de conduta socialmente aceitas. ${ }^{16}$ (CHAMBERS; TRUDGILL, 1980 apud FERNANDÉZ, 1998, p.38-39, tradução nossa).

Ainda há outros aspectos a considerar no que se refere ao valor social que uma forma de tratamento pode assumir em determinado contexto discursivo, cultural e histórico. Koch (2008) discute que há procedimentos linguísticos de tratamento indireto que se opõem ao direto e invasivo Tu pronominal. Trata-se da pluralização pronominal que, na língua portuguesa, constituiu-se com o

\footnotetext{
16 "Chambers y Trudgill, con un criterio que parte del concepto sociocultural de género, explican la tendencia de las mujeres a seguir los modelos de prestigio mediante los razonamientos siguientes: la falta de un lugar destacado en la sociedad hace que las mujeres necesiten marcar su estatus social mediante una conducta específica; por otra parte, la falta de cohesión de las mujeres en las redes sociales las obliga a enfrentarse más a menudo a situaciones de formalidad, esto es, el lugar del hombre en los intercambios sociales permite que consideren como de escasa formalidad muchas situaciones que las mujeres interpretan como más formales; finalmente, la educación suele llevar a las mujeres a desempeñar lo que se considera <<su>> función social siguiendo unas normas de conducta socialmente aceptadas." (CHAMBERS; TRUDGILL, 1980 apud FERNÁNDEZ, 1998, p.38-39).
} 
indireto Vós (plural majestático) (CINTRA, 1972) e com o tratamento nominal abstrato que, com base em um pronome possessivo aliado a um substantivo, refere-se indiretamente ao interlocutor, invocando-o como uma entidade abstrata. Nesse sentido, é possível entender que a mulher da família Pedreira Ferraz-Magalhães tende a optar, nas cartas familiares em estudo, pelo Você cujo grau de indiretividade é maior que o do íntimo Tu. Considerando o fato de o Você ser resultado do processo lento e gradual de pronominalização de Vossa Mercê, é possível admitir que tenha herdado de tal 'forma nominal abstrata' um grau de indiretividade. Ainda que, nas cartas pessoais trocadas entre irmãos, prevaleça o tom de intimidade com o direto $\mathbf{T u}$, as mulheres mostram-se mais propensas que os homens a empregar o inovador Você, movidas por uma espécie de "recato" linguístico que não as licenciava tratar o interlocutor com um Tu íntimo, muito mais invasivo, portanto, que o Você. Carboni e Maestri (2003), ao pensarem a expressão do gênero feminino nas línguas humanas, entendem-na com base no contexto sócio-histórico que a determina.

Na maioria das línguas, o gênero feminino dissolve-se por detrás do masculino, expressando ideologicamente a ocultação patriarcal objetiva da mulher pelo homem. Assim, naturalizado no uso costumeiro, o conceito linguístico, por meio do caráter aparentemente abrangente, sintético e neutro do gênero masculino, impõe sua essência social, reforçando as relações de dominação patriarcal do mundo real. (CARBONI; MAESTRI, 2003, p.61).

Em termos linguísticos, o fato de a figura feminina estar encoberta pela masculina é traduzido no paradoxo do gênero pensado porWolfram e SchillingEstes (1998 apud LABOV, 2001): se, por um lado, as mulheres mostram-se mais conservadoras que os homens, por preferirem a variante padrão, por outro lado, mostram-se mais avançadas, por adotarem, em menos tempo, a variante inovadora, que pode ou não corresponder à variante "não padrão". Ao propor a resolução do paradoxo do gênero, Labov (2001) o restabelece como o paradoxo da conformidade: as mulheres evidenciam um comportamento linguístico menos desviante que os homens em relação ao cumprimento da norma padrão, caso o desvio seja seriamente condenado. Entretanto, as mulheres mostram-se mais desviantes que os homens no que se refere ao exercício da norma padrão, quando a irregularidade não é gramaticalmente rechaçada (estigmatizada) pela comunidade linguística.

Por um lado, a mulher da família Pedreira Ferraz-Magalhães marcou a sua conduta linguística de submissão, ao empregar mais o Você que os homens como uma estratégia de tratar o interlocutor de modo mais monitorado e menos expressivo, em conformidade com os traços de [+ monitoramento], [- expressividade] atribuídos à forma Você por Modesto (2006) na análise 
sincrônica da fala santista. Por outro lado, ao eleger uma forma nova (Você), advinda de uma estratégia de prestígio (Vossa Mercê), conforme Cintra (1972), a mulher assumiu uma postura inovadora. O empreendedorismo linguístico das mulheres está no fato de selecionarem uma forma que se inseriu a posteriori no quadro pronominal do $\mathrm{PB}$ como resultado de um processo gradual e paulatino de uma mudança linguística de cima para baixo (change from above) (LABOV, 1994). Nesse sentido, dialoga-se com a primeira generalização proposta por Scherre e Yacovenco (2011, p.139) no que se refere ao fato de "as mulheres estarem à frente" em processos de mudança com consciência social (change from above) relacionados a fenômenos linguísticos menos marcados socialmente, como é o caso do contexto de inserção do Você na escrita culta do PB.

Há que se contextualizar a questão do inovadorismo linguístico atribuído por Labov (1990) às mulheres, para se reinterpretar tal fato em relação aos processos de variação e mudança que envolvem as formas pronominais Tu/Você no PB. Tendo em vista o fato de se tratar de mulheres nascidas no Brasil da segunda metade do século XIX, momento ainda marcado pela subserviência feminina à figura do homem, a opção pelo Você evidencia muito mais o cumprimento a um padrão social de submissão concretizado na opção feminina por tornar mais produtiva uma estratégia de referência ao interlocutor menos invasiva, logo, mais neutra, como é o caso do Você no PB. Ainda que consciente da implicação social do tratamento do seu interlocutor por Você, a mulher-missivista, nas eras oitocentista e novecentista do PB, prefere um pronome que está em processo de inserção no quadro pronominal da língua, dotado ainda de uma relativa formalidade, o que permite confirmar a hipótese Laboviana de que a mulher tende a se encaminhar na direção histórica da mudança linguística.

Labov, ao se questionar sobre o motivo de as mulheres serem mais sensíveis às formas de prestígio, chega à seguinte conclusão sobre o seu papel nos processos de mudança linguística.

Por que as mulheres fazem isso? Não pode ser apenas a sua sensibilidade às formas de prestígio, já que isso explica somente metade do padrão. Podemos dizer que elas são mais sensíveis aos padrões de prestígio, mas por que, desde o início, elas avançam mais rápido em primeiro lugar? Nossas respostas no momento não passam de especulações, mas é óbvio que tal comportamento das mulheres deve desempenhar um importante papel no mecanismo da mudança linguística. Na medida em que os pais influenciam a língua inicial das crianças, as mulheres influenciam mais ainda; as mulheres certamente conversam mais do que os homens com as criancinhas e têm uma influência mais direta durante os anos em que as crianças estão formando regras linguísticas com maior rapidez e eficácia. Parece provável que o ritmo do progresso e a direção da mudança 
linguística devem muito à especial sensibilidade das mulheres a todo o processo. (LABOV, 2008, p.347).

Em diálogo com Callou e Serra (2007), admite-se que a mulher brasileira, cuja história de formação é permeada pela exclusão ao conhecimento (ao saber veiculado através do ensino formal), ao fugir do caráter mais íntimo (invasivo) do Tu, opta, no seio da sociedade brasileira oitocentista e novecentista, pelo tom de neutralidade conferido ao Você, "seguindo à frente", por volta dos anos 30 do século XX, no processo de inserção de tal forma no sistema pronominal do PB.

[...] não se pode deixar de relacionar a história linguística à história social. Três fatores devem ser observados, de início, mais de perto: [...] O terceiro é o de o primeiro contato do indivíduo com a língua se dar no âmbito familiar e o de as mulheres serem, de um lado, em geral, segundo Labov (2001), as transmissoras das mudanças linguísticas e, por outro lado, terem ficado, durante muito tempo, afastadas do sistema educacional regular. (CALLOU; SERRA, 2007, p.461-462).

RUMEU, M. C. de B. The Variation Between "tu" and "você" in 19th and 20th Century Brazilian Portuguese: discussions on the social category gender. Alfa, São Paulo, v.57, n.2, p.545-576, 2013.

- ABSTRACT: In this text, the social category Gender is discussed in order to interpret the embedding process of Você in Brazilian Portuguese (BP). Based on the analysis of 1 gth $^{\text {th }}$ and $20^{\text {th }}$ century personal letters, written by educated Brazilians, members of a same Brazilian family (the Pedreira Ferraz-Magalhães family), whose sociolinguistic profiles have been identified (LOBO, 2001), the results of a panel study (LABOV, 1994) are discussed. These are focused on past synchronies of BP, related to the forms of Tu and Você as pronominal subjects. The result is that Você, used informally in Brazilian letters between the 20s and 30s of the 20 ${ }^{\text {th }}$ Century, is in an advanced stage of linguistic change, this process being led by women. The results of the Tu/Você variation study, performed by Pereira (2012) can be added to this discussion, based on letters written by Brazilians from the distinguished Penna family towards the end of the $19^{\text {th }}$ and the first half of the $20^{\text {th }}$ centuries. The letters expound Gender as a propelling social category of the embedding of Você in the pronominal system of $19^{\text {th }}$ and $20^{\text {th }}$ century Brazilian Portuguese.

- KEYWORDS: Tu/Você variation. Linguistic change. Gender. Forms of pronominal address. Pronominal system.

\section{REFERÊNCIAS}

AGUILLAR, R. C. Presencia de lo oral en lo escrito: la transcripción de las declaraciones en documentos indianos del siglo XVI. In: OESTERREICHER, W.; STOLL, E.; WESCH, A. (Ed.). Competencia escrita, tradiciones discursivas y variedades linguísticas: aspectos del español europeo y americano en los siglos XVI y XVII. Tubingen: Narr, 1998. p.239-240. 
BARBOSA, A. G. Tratamento dos corpora de sincronias passadas da língua portuguesa no Brasil: recortes grafológicos e linguísticos. In: LOPES, C. R. dos S. (Org.). A norma brasileira em construção: fatos linguísticos em cartas pessoais do século XIX. Rio de Janeiro: Ed. da UFRJ, 2005. p.25-43.

. Para uma história do português colonial: aspectos linguísticos em cartas de comércio. 1999. 293f. Tese (Doutorado em Língua Portuguesa) - Faculdade de Letras, Universidade Federal do Rio de Janeiro, Rio de Janeiro, 1999.

BARCIA, L. R. As formas de tratamento em cartas de leitores oitocentistas: peculiaridades do gênero e reflexos da mudança pronominal. 2006. 142f. Dissertação (Mestrado em Língua Portuguesa) - Faculdade de Letras, Universidade Federal do Rio de Janeiro, Rio de Janeiro, 2006.

CALLOU, D.; SERRA, C. Aspectos da história demográfica e social do Rio de Janeiro: escolarização, norma e nacionalidade. In: RAMOS, J.; ALKMIM, M. A. (Org.). Para a história do português brasileiro. Belo Horizonte: Faculdade de Letras da UFMG, 2007. v.5. p.443-463.

CARBONI, F.; MAESTRI, M. A linguagem escravizada: língua, história, poder e luta de classes. São Paulo: Expressão Popular, 2003.

CASTRO, J. P. de. Zélia ou Irmã Maria do SS. Sacramento: vida exemplar de uma mãe cristã, que terminou seus dias junto a Jesus Sacramentado. 7.ed. Petrópolis: Vozes, 1960.

CINTRA, L. F. L. Sobre "formas de tratamento" na língua portuguesa. Lisboa: Livros Horizonte, 1972.

CUNHA, C. A questão da norma culta. Rio de Janeiro: Tempo Brasileiro, 1985.

DUARTE, M. E. L. A perda do princípio 'Evite pronome' no português brasileiro. 1995. 151f. Tese (Doutorado em Linguística) - Instituto de Estudos de Linguagem, Universidade Estadual de Campinas, Campinas, 1995.

FERNÁNDEZ, F. M. Princípios de sociolinguística y sociología del lenguaje. Espanha: Editorial Ariel, 1998.

GUY, G.; ZILLES, A. Sociolinguística quantitativa: instrumental de análise. São Paulo: Parábola, 2007.

ILARI, R. Linguística Românica. São Paulo: Ática, 2002.

$\mathrm{KOCH}, \mathrm{P}$. Tradiciones discursivas y cambio linguístico: el ejemplo del tratamiento vuestra merced en español. In: KABATEK, J. (Ed.). Sintaxis histórica del español y cambio linguístico: nuevas perspectivas desde las tradiciones discursivas. Madrid: Vervuert, 2008. p.53-88.

LABOV, W. Padrões sociolinguísticos. São Paulo: Parábola, 2008. 
Principles of linguistic change: social factors. Cambridge: Blackwell Publishers, 2001. v.2.

Principles of linguistic change: internal factors. Cambridge: Blackwell Publishers, 1994. v.1.

. The intersection of sex and social class in the course of linguistic change. Language variation and change, Cambrigde, v.2, n.2, p.135-56, 1990.

LOBO, T. C. F. Para uma sociolinguística histórica do português no Brasil: edição filológica e análise linguística de cartas particulares do Recôncavo da Bahia, século XIX. 2001. 248f. Tese (Doutorado em Filologia e Língua Portuguesa) - Faculdade de Filosofia, Letras e Ciências Humanas, Universidade de São Paulo, São Paulo, 2001. $4 \mathrm{v}$.

LOPES, C. R. S.; DUARTE, M. E. L. De "vossa mercê" a "você": análise da pronominalização de nominais em peças brasileiras e portuguesas setecentistas e oitocentistas. In: BRANDÃO, S. F.; MOTA, M. A. (Org.). Análise contrastiva de variedades do português: primeiros estudos. Rio de Janeiro: In-fólio, 2003. p.61-73.

LOPES, C. R. S.; MACHADO, A. C. M. Tradição e inovação: indícios do sincretismo entre a segunda e a terceira pessoas nas cartas dos avós. In: LOPES, C. R. S. (Org.). A norma brasileira em construção: fatos linguísticos em cartas pessoais do século XIX. Rio de Janeiro: Ed. da UFRJ, 2005. p.45-66.

LOPES, C. R. S.; MARCOTULIO, L. L.; RUMEU, M. C. B. O tratamento em bilhetes amorosos no início do século XX: do condicionamento estrutural ao sociopragmático. In: COUTO, L. R. C.; LOPES, C. R. S. (Org.). As formas de tratamento em português e em espanhol: variação, mudança e funções conversacionais. Niterói: UFF, 2011. p.315-348.

LOPES, C. R. S. et al. Sobre norma e tratamento em cartas a Rui Barbosa. In: AGUILERA, V. (Org.). Para a história do português brasileiro. Londrina: Ed. da UEL, 2009. p.45-92. v.7.

MACHADO, A. C. M. A implementação de "você" no quadro pronominal: as estratégias de referência ao interlocutor em peças teatrais no século XX. 2006. 108f. Dissertação (Mestrado em Língua Portuguesa) - Faculdade de Letras, Universidade Federal do Rio de Janeiro, Rio de Janeiro, 2006.

MARCOTULIO, L. L. A preservação das faces e a construção da imagem no discurso político do Marquês do Lavradio: as formas de tratamento como estratégias de atenuação da polidez linguística. 2008. 215f. Dissertação (Mestrado em Língua Portuguesa) - Faculdade de Letras, Universidade Federal do Rio de Janeiro, Rio de Janeiro, 2008. 
MENON, O. P. S. A história de você. In: GUEDES, M.; BERLINCK, R. A.; MURAKAWA, C. A. A. (Org). Teoria e análise linguísticas: novas trilhas. Araraquara: Laboratório Editorial FCL/UNESP; São Paulo: Cultura Acadêmica Editorial, 2006. p.99-160.

MODESTO, A. T. T. Formas de tratamento no português brasileiro: a alternância Tu/Você na cidade de Santos - SP. 2006. 128f. Dissertação (Mestrado em Letras) - Faculdade de Filosofia, Letras e Ciências Humanas, Universidade de São Paulo, São Paulo, 2006.

MOLLICA, M. C.; BRAGA, M. L. (Org.). Introdução à sociolinguística: o tratamento da variação. São Paulo: Contexto, 2004.

OMENA, N. P. As influências sociais na variação entre nós e a gente na função de sujeito. In: SILVA, G. M. O. e.; SCHERRE, M. M. P. Padrões sociolinguísticos: análise de fenômenos variáveis do português falado na cidade do Rio de Janeiro. Rio de Janeiro: Tempo Brasileiro, 1996. p.309-324.

PAGOTTO, E. G. Norma e condescendência: ciência e pureza. Línguas e Instrumentos Linguísticos, São Paulo, v.2, p.49-68,1999.

PAIVA, M. C. A variável gênero/sexo. In: MOLLICA, M. C.; BRAGA, M. L. (Org.). Introdução à sociolinguística: o tratamento da variação. São Paulo: Contexto, 2004. p.33-42.

PAIVA, M. C.; DUARTE, M. E. L. (Org.). Mudança linguística em tempo real. Rio de Janeiro: Contra Capa, 2003.

PEREIRA, R. O. O tratamento em cartas amorosas e familiares da Família Penna: um estudo diacrônico. 2012. 142f. Dissertação (Mestrado em Língua Portuguesa) Faculdade de Letras, Universidade Federal do Rio de Janeiro, Rio de Janeiro, 2012.

RAUMOLIN-BRUNBERG, H. The diffusion of subject YOU: a case study in historical sociolinguistics. Language Variation and Change, Cambrigde, v.17, p.55-73, 2005.

RUMEU, M. C. B. A implementação do 'você' no português brasileiro oitocentista e novecentista: um estudo de painel. 2008. 928 f. Tese (Doutorado em Língua Portuguesa) - Faculdade de Letras, Universidade Federal do Rio de Janeiro, Rio de Janeiro, 2008. 2v.

. Para uma história do português no Brasil: formas pronominais e nominais de tratamento em cartas setecentistas e oitocentistas. 2004. 288 f. Dissertação (Mestrado em Língua Portuguesa) - Faculdade de Letras, Universidade Federal do Rio de Janeiro, Rio de Janeiro, 2004. 2v.

SAMARA, E. de M. A família brasileira. São Paulo: Brasiliense, 2004.

SAUSSURE, F. Curso de Linguística Geral. São Paulo: Cultrix, 1969. 
SCHERRE, M. M. P.; YACOVENCO, L. C. A variação linguística e o papel dos fatores sociais: o gênero do falante em foco. Revista da ABRALIN, Natal, v.eletrônico, nesp., p.121-146, 2011. Disponível em: <http://www.abralin.org/site/data/uploads/ revistas/2011-vol-especial-1o-parte/a-variacao-linguistica-2.pdf>. Acesso em: 05 ago. 2012 .

SCHERRE, M. M. P. et al. Usos dos pronomes vocêe tu no português brasileiro. In: SIMELP: SIMPÓSIO MUNDIAL DE ESTUDOS DE LÍNGUA PORTUGUESA, 2009, Évora. Apresentação de Trabalho. Évora: Universidade de Évora, 2009.

SILVA, G. M. O. e. Coleta de dados. In: MOLLICA, M. C. (Org.). Introdução à sociolinguística variacionista: cadernos didáticos. Rio de Janeiro: Ed. da UFRJ, 1992. p.101-114.

SILVA, V. L. P. A variação você/tu na fala carioca. In: ENCONTRO DE VARIAÇÃO LINGUÍSTICA DO CONE SUL, 1., 1996, Porto Alegre. Anais... Porto Alegre:UFRGS, 1996. Não paginado.

SOTO, E. U. M. S. Cartas através do tempo: o lugar do outro na correspondência brasileira. Niterói: Ed. da UFF, 2007.

Variação/mudança do pronome de tratamento alocutivo: uma análise enunciativa em cartas brasileiras. 2001. 264f. Tese (Doutorado em Linguística) Faculdade de Ciências e Letras, Universidade Estadual Paulista, Araraquara, 2001.

SUNDGREN, E. Men and women in language change: a swedish case study. NORA, New York, v.9, n.2, p.113-123, 2001.

WEINREICH, U.; LABOV,W.; HERZOG, M. I. Empirical foundations for a theory of language change. In: LEHMANN, W.; MALKIEL, Y. (Ed.). Directions for historical linguistics. Austin-London: University of Texas Press, 1968. p.95-195.

ZILLES, A. M. The development of a new pronoun: the linguistic and social embedding of a gente in brazilian portuguese. Language Variation and Change, Cambrigde, v.17, p.19-53, 2005.

\section{Bibliografia consultada}

PAIVA, M. C.; DUARTE, M. E. L. Mudança linguística: observações no tempo real. In: MOLLICA, M. C.; BRAGA, M. L. (Org.). Introdução à sociolinguística: o tratamento da variação. São Paulo: Contexto, 2004. p.179-190.

Recebido em março de 2012

Aprovado em novembro de 2012 